\title{
Uraemic lung in severe azotaemia
}

\author{
Sheng-Hsiang Lin, ${ }^{1,2}$ Wan-Hsiu Liao, ${ }^{3}$ Shih-Horng Huang ${ }^{4}$
}

1 Department of Internal Medicine, New Taipei City Hospital, New Taipei, Taiwan ${ }^{2}$ Department of Respiratory Therapy, Fu-Jen Catholic University, New Taipei, Taiwan ${ }^{3}$ Department of Family Medicine, New Taipei City Hospital, New Taipei City, Taiwan

${ }^{4}$ Department of Surgery, New Taipei City Hospital, New Taipei, Taiwan

\section{Correspondence to} Dr Sheng-Hsiang Lin, linsh01@gmail.com

To cite: Lin S-H, Liao, W-H,
Huang S-H. BMJ Case Rep
Published online: [please
include Day Month Year]
doi:10.1136/bcr-2013-
200966

\section{DESCRIPTION}

A 70-year-old man, a case of diabetes mellitus with nephropathy, presented with malaise, poor appetite and progressive shortness of breath for 1 week. Physical examination showed crackles at bilateral lung fields and no oedema of limbs. His blood urea nitrogen (BUN) and serum creatine levels were 245 and $33 \mathrm{mg} / \mathrm{dL}$, respectively. Anaemia (haemoglobin $6.4 \mathrm{~g} / \mathrm{dL}$ ) and hypoalbuminaemia (albumin $2.6 \mathrm{~g} /$ $\mathrm{dL}$ ) were also noticed. The ECG showed a sinus rhythm without significant ST-T wave changes. Chest radiography showed bilateral perihilar pulmonary consolidations with a clear periphery (figure 1A). He was haemodialysed for uraemia with uraemic lung. One week later, the levels of BUN $(103 \mathrm{mg} / \mathrm{dL})$ and serum creatine $(14.5 \mathrm{mg} / \mathrm{dL})$ decreased and without a significantly negative fluid balance, complete resolution of pulmonary opacities was achieved in the follow-up chest radiography (figure 1B).

Uraemic lung is a severe pulmonary complication observed in patients with uraemia. ${ }^{1}$ Besides fluid overload, it could be attributed to miscellaneous mechanisms, such as increased lung vascular permeability and inflammation induced by chemokines and leucocytes. ${ }^{12}$ It is important to differentiate uraemic lung from other causes of lung oedema. A previous radiology study had shown that more lung oedema in renal failure had central distribution of pulmonary opacities while more lung oedema in heart failure had cephalisation of pulmonary vessels. ${ }^{3}$ Likewise, the reported cases of uraemic lung were characterised by perihilar opacities with a clear periphery. ${ }^{1}$ Although uraemia related distant organ damage still has a substantial impact on mortality, dialysis remains the most important treatment for a better outcome. ${ }^{2}$

\section{Learning points}

- Uraemic lung is related to a variety of causes, including fluid overload, increased lung vascular permeability and inflammation; nonetheless, the diagnosis must be established after the exclusion of pure hydrostatic lung oedema.

- The chest radiographic findings of uraemic lung are characterised by perihilar consolidations with a clear periphery.

- Adequate dialysis is the mainstay of treatment for uraemic lung.

Contributors All the authors have contributed in preparing the manuscript, writing the case report, taking decision regarding publication.

Competing interests None.

Patient consent Obtained.

Provenance and peer review Not commissioned; externally peer reviewed.

\section{REFERENCES}

1 Doi K, Ishizu T, Fujita T, et al. Lung injury following acute kidney injury: kidney-lung crosstalk. Clin Exp Nephrol 2011;15:464-70.

2 Scheel PJ, Liu M, Rabb H. Uremic lung: new insights into a forgotten condition. Kidney Int 2008;74:849-51.

3 Miniati M, Pistolesi $\mathrm{M}$, Paoletti $\mathrm{P}$, et al. Objective radiographic criteria to differentiate cardiac, renal, and injury lung edema. Invest Radiol 1988:23:433-40.

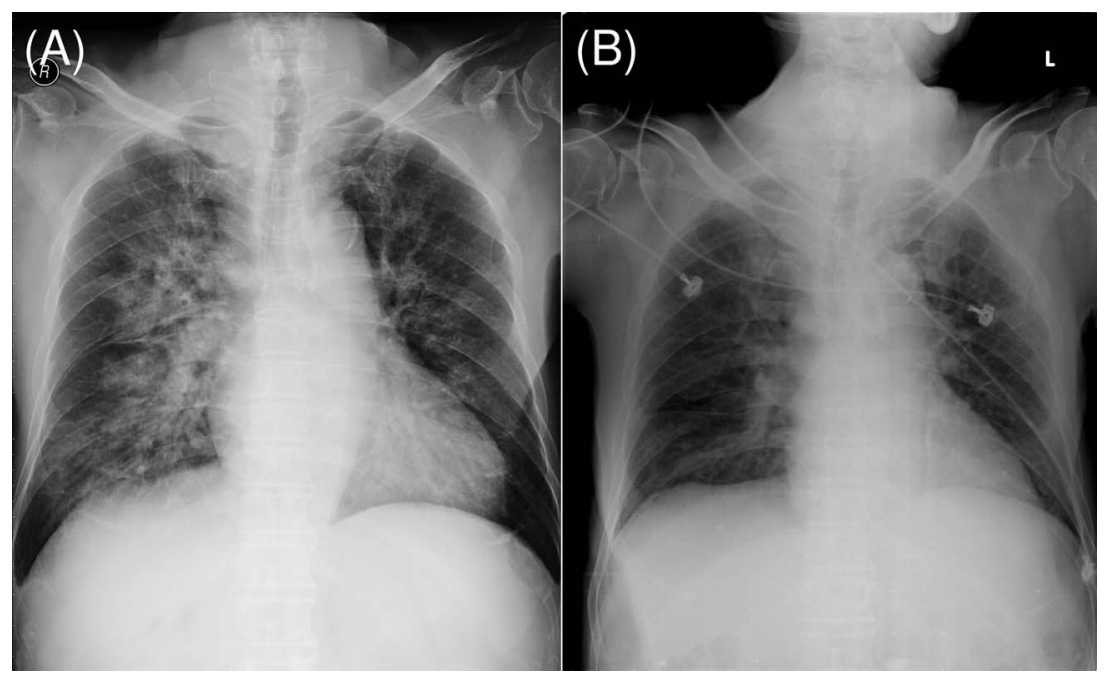

Figure 1 (A) Chest X-ray at arrival showing bilateral perihilar consolidations with right lung predominance. (B) chest $\mathrm{X}$-ray 1 week later showing complete resolution of pulmonary consolidations. 
Copyright 2013 BMJ Publishing Group. All rights reserved. For permission to reuse any of this content visit http://group.bmj.com/group/rights-licensing/permissions.

BMJ Case Report Fellows may re-use this article for personal use and teaching without any further permission.

Become a Fellow of BMJ Case Reports today and you can:

- Submit as many cases as you like

- Enjoy fast sympathetic peer review and rapid publication of accepted articles

- Access all the published articles

- Re-use any of the published material for personal use and teaching without further permission

For information on Institutional Fellowships contact consortiasales@bmjgroup.com

Visit casereports.bmj.com for more articles like this and to become a Fellow 